\title{
METHODOLOGICAL FRAMEWORK FOR MODELLING INTEGRATION RISKS IN ECONOMIC EMERGENCE
}

\author{
VIKTORIYA HUROCHKINA \\ University of the State Fiscal Service of Ukraine \\ ORCID: https://orcid.org/0000-0001-8869-0189 \\ e-mail: viktoriav2005@ukr.net
}

\begin{abstract}
The article discusses the methodological basis for modeling integration risks of the social and economic system, namely the association of enterprises and organizations in the value-added chain in the context of the emergent economy. The theoretical basis and practical aspects of the risk-taking of integration processes were presented, features of integration and methods of risk modeling in value chains in socio-economic systems were identified. Systematized taxonomic survey of emergent state of socio-economic system has been developed. The components of the integration of enterprises in the context of the formation of value chains are presented and the most efficient modeling methods in unstable environments have been identified. The algorithm of comparative estimation of emergent properties with dual poles of results of functioning of economic system and structural organization of system of modeling of indicators of emergencies taking into account influence of integration risks is presented. The methodological bases for the modeling of indicators under the influence of investment risks based on fuzzy logic according to system safety criterion are presented, A comparative assessment framewo rk for modeling integration risks in value chains and a framework for modeling integration risks of economic potential and strategic resilience of the socio-economic system. It is noted that the method of comparative evaluation serves as an indicator of compliance of the conclusions of the model of dynamic chaos, which has a dual attractor and depends on the phase portrait. The taxonomy of the emergent state of the economic system serves to identify the integral values of innovative reflection and is to identify new properties that characterize the influence of the external environment on changes in the whole system with varying degrees of resonance. Peculiarities of modeling of integration factors at the bifurcation point when positive and negative emergent properties arise are highlighted. The vectors of the integration process, which depend on the adaptation potential of the new structural units (institutions), should be included in the formation of the model. The key factors and indicators influencing the sensitivity of economic potential and strategic elasticity of the system of value chains of enterprises are identified.
\end{abstract}

Keywords: system, modeling, emergence, emergent properties, taxonomy, integration risks.

DOI: 10.31891/mdes/2021-1-3

\section{INTRODUCTION}

To study the methodological basis for modeling integration risks of the system (value chains of enterprises) in economic emergence, it is necessary to consider the theoretical basis and to define practical aspects of the risk-taking of integration processes in Ukraine, to define features of integration and methods of risk modeling in value chains in social-economic systems. Develop taxonomies of emergent states of the economic system. Present the components of enterprise integration in the context of value chain formation and identify the main modeling techniques focusing on the most efficient in a unstable environment.

\subsection{Literary analysis}

\section{OVERVIEW OF THE RESEARCH AND GOAL FORMULATION}

The issue of security of integration processes in value chains in socio-economic systems and ensuring their development in the domestic market has been highlighted in many professional works, among which Voynarenko M.P. [8,9,10] Hryhoruk P.N. [1,2,7, 12, 13], Gonchar O. I. [11], Grygoruk S. [7], Dzhedzhula V.V. [8,10], Yepifanova I.Y. [8,10], Kindzersky Y. V. [6], Kovalenko A.A. [9], Menchynska A. N. [9], Khrushch N.A. [9, 12, 13], and other domestic and foreign scientists. Analysis of the theoretical basis of the methodological bases for modeling integration risks of the system (value chains of enterprises) in the emergent economy and definition of practical aspects of modeling the system of prevention of integration processes in the domestic market of Ukraine.

1.2. Presentation of the main material of the study.

The integration risks in economic emergence reflect the dangerous phenomena that arise at different stages of the integration process at the same time create a field of dualistic nature of emergent states. Under the influence of unpredictable integration factors at the bifurcation point there are positive and negative properties, which we call emergent. The diversity of the integration process is inevitable, and the direction depends on the characteristics of the adaptation potential of new structural units (institutions). With a low level of adaptive potential, there is a high probability of deterministic chaos of the integration association.

In examining the integration of industrial enterprises in the context of value chain formation, it is necessary to start from the quality of the management decisions of the actors in the integration process and the resources available, This is what determines whether the value chain is circular or linear. The circular 
value chain is based on the achievement of environmental benefits through processing (redesign or recycling), which prolongs the useful life of goods and products. The increased effectiveness of integration cooperation comes after the creation of new structures and institutions, and affects the achievement of strategic elasticity of the integrated structure of enterprises and organizations. The components of the integration of industrial enterprises into the system are presented in Fig. 1.

Objective conditions for the establishment of integration mechanisms are the needs of the economy and the state of the sector, which are based on technological reasons and monopolistic aspirations and are aimed at reducing costs. Integration arrangements provide an opportunity to attract investment or achieve capital consolidation with a view to generating high profits. Strategic advantages for members of integrated structures are the competitive advantages that participants derive from the transfer of technology, knowledge and skills in value chains. The drivers of competitive advantages are the activation of latent manifestations of emergent properties, prompting technological development, providing resources, conquering the market, etc. With the achievement of a high level of financial safety of the enterprise and protection of stakeholder interests in the investment policy of the industrial enterprise, the efficiency of integration cooperation is enhanced to ensure strategic elasticity of the structure of industrial integration enterprises. The effectiveness of the consolidation of mechanisms for the development of industrial enterprises makes it necessary for subjects to use and realize investments in industrial enterprises to fulfill functional duties aimed at the protection of financial resources and investment capital stakeholder.

Under the investment risk management framework, a significant role should be played by systematic quantitative and qualitative analysis, which is carried out in the sequence «the nature of the risk of possible consequences of risk factors (factors)». It should take into account the sources of external and internal factors, the degree of influence of direct and indirect factors, the nature of the regulation of factors, and should be regulated, unregulated or difficult to regulate. Factors that manage risks, factors that are difficult to manage are crises, and factors that are not controlled by shocks at all. In most cases, it is shocks that trigger economies in the management of the financial mechanisms of industrial enterprises financial crises, that is, shock as a destructive force with a special nature and extremely negative consequences, can destroy the strategic resilience of the cluster structure.

The concept of development of the emergent socio-economic system is based on the theory of chaos, in which we view it as a factor of renewal and a trigger for transition to another state. In the concept of industrial development, periods of chaos in the economy are considered as effective points of bifurcation for self-organization of economic systems [5, pp. 122, 3, 4]. Emergence defines the facts of the acquisition of new properties by the system based on the effects of adaptation and stability (positive properties) and the effects of resonance (negative properties). For the purpose of activation of emergent properties in unstable environment preliminary in work [5, pp. 113, 3, 4] an algorithm for comparison of emergent properties with dual poles of results / the inverse function of a bath of an economic system of bifurcation character was developed. This scientific and practical approach to measuring the fluctuation of indicators is based on the importance of the upper sections of the average performance of the components of the reference economic system. The reference methodology is based on an average sample of the dynamic processes of the economic system (fig. 2). The taxonomy of the emergent state of the economic system, as the process of identifying and generalizing the integral values of innovation reflex, is reduced to the identification of new properties that characterize the influence of the external environment on the changes of the whole system with different degree of resonance.

For taxonomic analysis, the emergent states represent the features of the system, grouped in a table. 1. Integration risks of value chains of enterprises and organizations in the emergent economy should be considered taking into account the taxonomy of the emergent state of the system.

\section{Comparative evaluation}

The modeling of integration risks in value-added chains in emergent economies for the purposes of their bias is carried out by the algorithm of comparative evaluation of emergent properties with the dual poles of the results of the functioning of the economic system. This approach makes it possible to determine the recurrence of emergent phenomena in an unstable environment.

The method of comparative evaluation is an indicator of the consistency of the conclusions of the dynamic chaos model, which has a dual attractor and depends on the phase portrait. The preconceived notions of integration risks provide an opportunity to enter the established mode of operation of the economic system. 


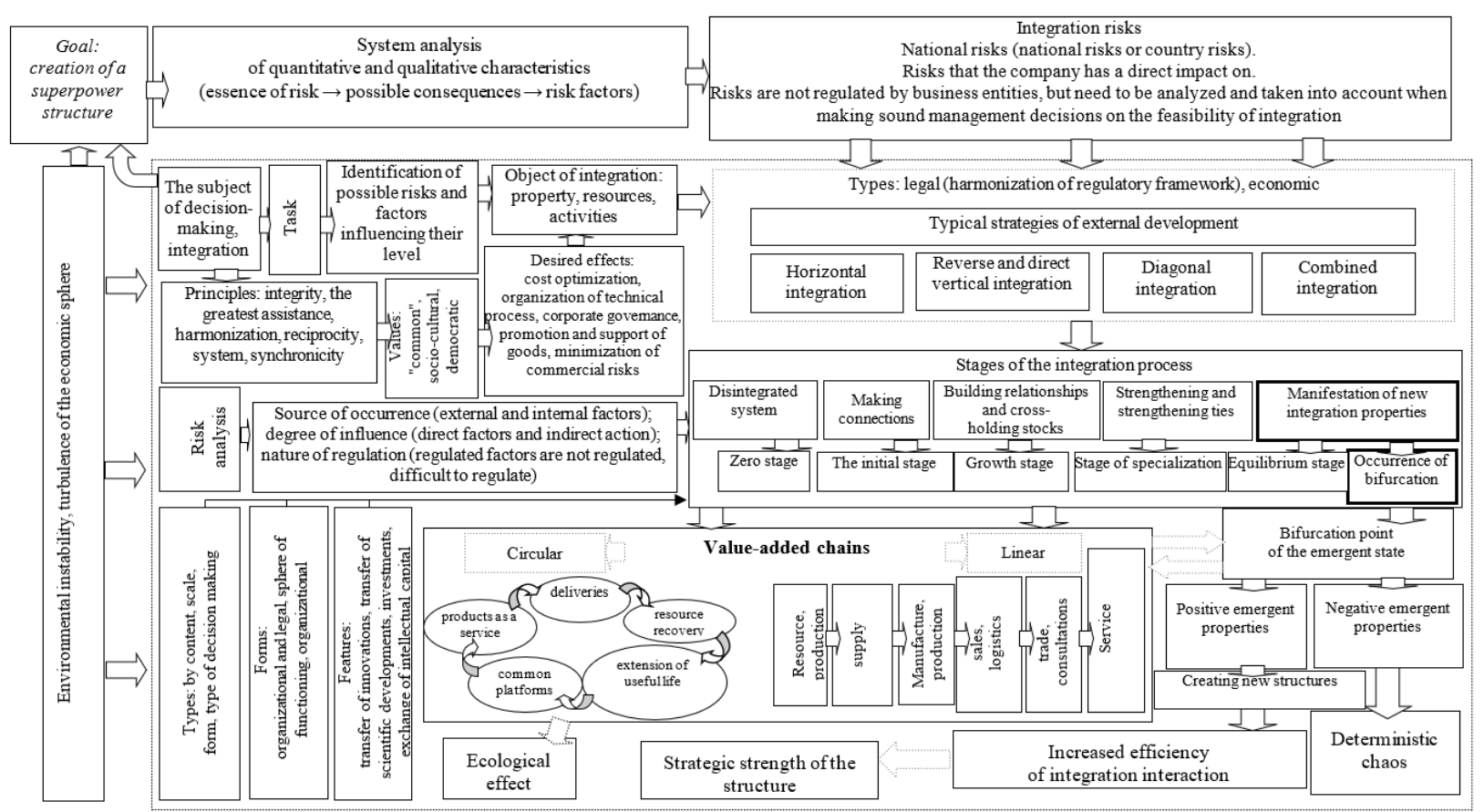

Figure 1. Components of the mechanism of integration of enterprises in the context of the formation of value chains * made by author

Table 1

Taxonomy of the emergent state of the system *

\begin{tabular}{|l|l|}
\hline \multicolumn{1}{|c|}{ Characteristic features } & \multicolumn{1}{|c|}{ Components, content } \\
\hline $\begin{array}{l}\text { The scale of the } \\
\text { emerging phenomena }\end{array}$ & $\begin{array}{l}\text { Emergence of new properties of chaos or qualitative structural changes (structuring and } \\
\text { transformation) }\end{array}$ \\
\hline $\begin{array}{l}\text { Role in ensuring } \\
\text { reliability }\end{array}$ & $\begin{array}{l}\text { Strength and stability of the system structure (organizational, financial, stability of social ties, } \\
\text { strong interaction, stability of the biosphere, compliance and strength of environmental } \\
\text { knowledge, etc.) }\end{array}$ \\
\hline Role in security & The structure has resonance effects (multilayer, chaotic processes) \\
\hline $\begin{array}{l}\text { The role of influencing } \\
\text { factors in ensuring } \\
\text { development }\end{array}$ & $\begin{array}{l}\text { Resilience, stress resistance, adaptation to the level of a certain time lag, compared with global } \\
\text { and national trends in the functioning of the subjects of integration relations }\end{array}$ \\
\hline $\begin{array}{l}\text { Regularities and trends } \\
\text { Qmade by author. }\end{array}$ & $\begin{array}{l}\text { Qualities of attraction of emergent characteristics of development / degradation of economic } \\
\text { system or subjects of integration relations to the negative or positive pole and their recurrence } \\
\text { (recurrence) in an unstable environment }\end{array}$ \\
\hline Building networks and relationships, common starting points, dominance and subordination \\
\hline
\end{tabular}

\section{Theoretical principles of micro simulation modeling}

In modeling indicators under the influence of investment risks on the basis of fuzzy logic, the security criterion is the value added resulting from interaction with the external environment, which the system can dispose of at its discretion. In the absence of profit or, indeed, loss, it is not possible to speak of the interests of the system and therefore of the security of the system.

It is believed that the approach to analyzing integration risks can be significantly strengthened by combining quantitative (financial) and qualitative (indicator) indicators in analysis, not only in static but also in dynamic terms, using a vague approach.

The theory of fuzzy sets has found a fairly wide application in the study of emergent types of economics. However, in the practice of value chain enterprises, these methods are rarely used as a system. In order to prevent integration risks into the emergent economic system, fuzzy models are developed, which in turn are formed on the basis of a determination of the interrelationship and quality characteristics of the social and economic unit (fig. 3).

The task of selecting risk parameters is to analyze the primary information, to process it for quantitative and qualitative indicators; the task of forming a model structure is to define the relationships between parameters; The problem of optimization is to compare the data with the necessary or extreme results, and finally, the problem of identification is to form the context of understanding the model results, 
their interpretation and identification with expert knowledge. The schematic image of the modeling system is shown in Fig. 4. The model library is the basis for the enterprise knowledge base.

Such a system of themes involves the modeling of an integral measure of emancipation, taking into account the influence of integration risks on the chain and the formation of variation patterns and recommendations for change of activities, the introduction of negative projection measures and the like.

Since the distribution of the shock by enterprises in strategic clusters or clusters may vary, Therefore, in order to determine the potential for a shock, it is advisable to identify differences in the economic potential of each enterprise, that is to say, the presence of resonant (amplification and impulses) or non-resonant (mildness and impulses) of factors. By systematizing the information, groups of factors influencing the economic potential of the value chain are identified:

1) the level of competitiveness of economic potential, which increases with increasing dynamic chaos, and with increasing level structures and strengthens the system, dominates and suppresses the effects of shocks;

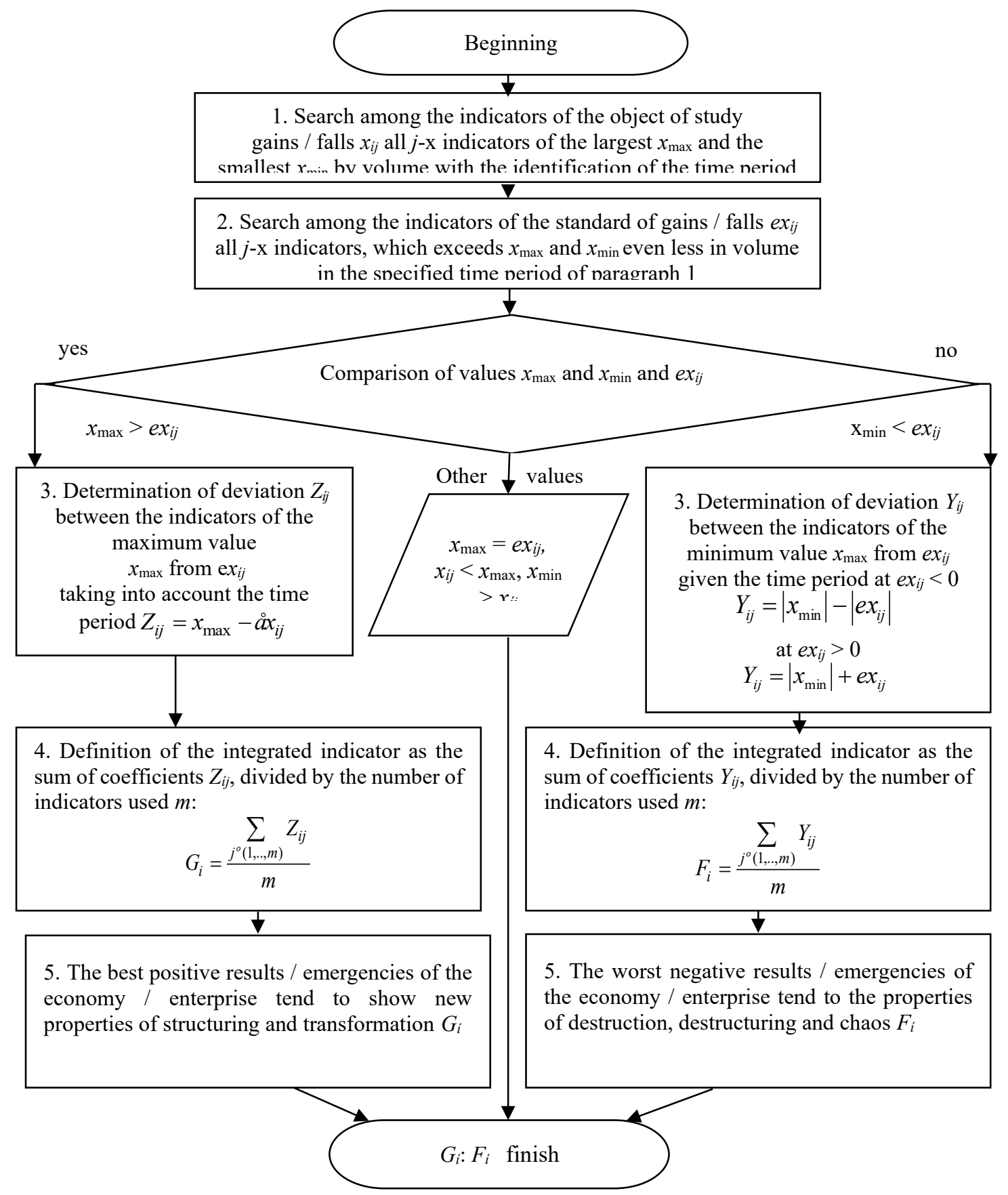
*made by author.

Figure 2. Algorithm for comparison of emergent properties with duals of the results of the economic system. 
2) the degree of diversification of the production structure of associations or clusters;

3) the degree of openness and scale of penetration of external changes;

4) activity of investment relations of enterprises;

5) geographical location of territorial areas in the economic space;

6) the starting level of economic development of the industrial enterprise and the growth rate of production;

7) living standards and purchasing power.

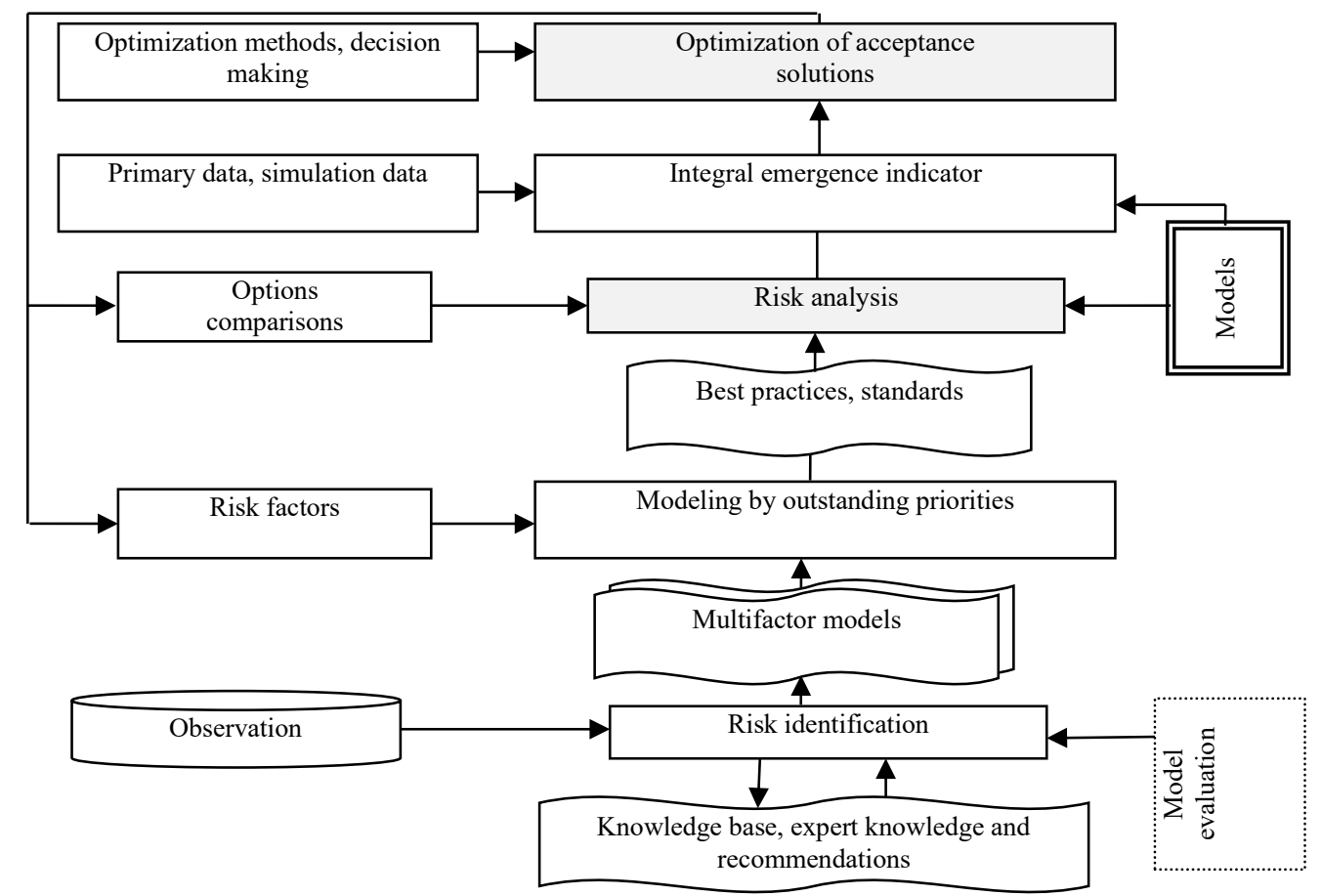

Fig. 3. Relationship between risk identification, analysis and optimization in the emergent socio-economic system * *made by author.

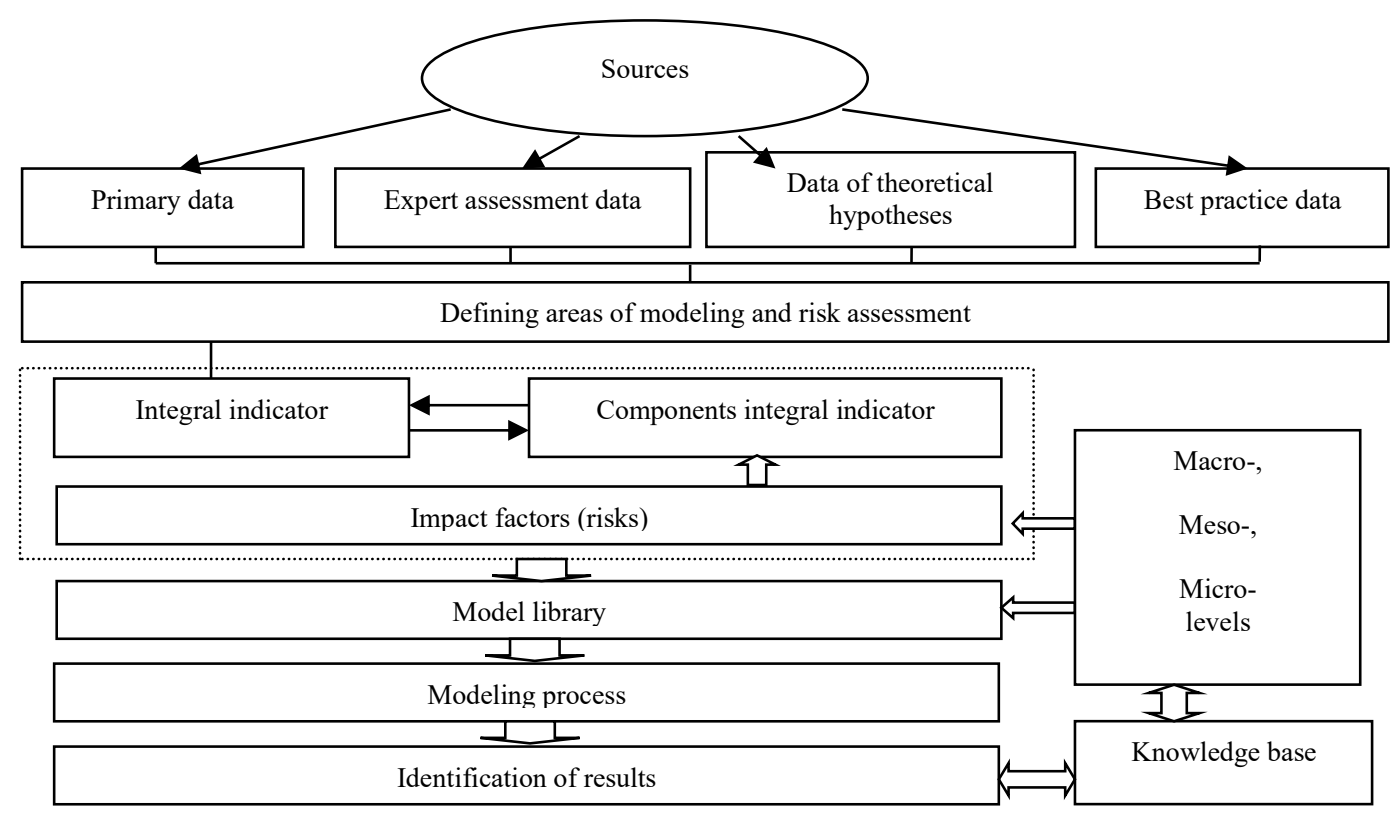

Fig. 4. Structural organization of the Emergence Metrics Modeling System for the Impact of Integration Risks * "Made by author.

The high-profile factors and their concentration influence the vulnerability of the economic potential, as well as the short-term variation of individual parameters (employment, price level, output level)In the long run, a shift in the direction of economic development away from patterns and trends has historically taken place. Taking into account the theories of economic thinking, the work systematizes the 
factors of the impact of the shock and its estimation, which influences the economic potential and strategic resilience of industrial enterprises.

Framework for modeling integration risks of economic potential and strategic resilience of the system.

Of course, not all factors can be taken into account in analyzing the sensitivity of economic potential and the strategic resilience of the structure of value chains of enterprises to external institutional and financial shocks. The following is the analysis of factors (Tab. 2) which are the main channels of penetration of shock calls. The salient factors and the theoretical content of their influence on the economic potential and the strategic elasticity of the value-added chain system of enterprises are systematized in terms of the investment channels for the communication of cash flows.

Table 2

Factors and indicators affecting the sensitivities of economic potential and strategic resilience of value chains of enterprises *

\begin{tabular}{|c|c|c|}
\hline Factors & Indicators / calculation mechanism & Influence \\
\hline \multicolumn{3}{|c|}{ Value chain chains } \\
\hline 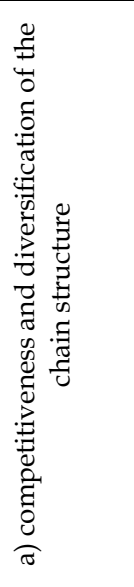 & $\begin{array}{l}\text { The volume of production per employee (thousand UAH / } \\
\text { person) and the increase in the indicator, \% } \\
\Delta Q_{1 \Pi p}=\frac{Q_{k}-Q_{\Pi}}{\mathrm{U}_{k}-\mathrm{\Psi}_{\Pi}} \cdot 100 \% \\
\Psi_{\kappa, n} \text { - number of employees at the end and beginning of the } \\
\text { year, persons } \\
\text { Chain diversification coefficient } \mathrm{K}_{d}=\frac{\sum\left(K_{i}^{\text {part }}-\overline{\mathrm{K}}^{2}\right.}{n} \\
K_{i}^{\text {part }} \text { - structural coefficient of the company's share in the } \\
\text { value chain, } \\
\overline{\mathrm{K}} \text { - the average value of the coefficients of participation in the } \\
\text { chain, n- the number of enterprises in the chain. }\end{array}$ & $\begin{array}{l}\text { The high level of development of the economic } \\
\text { potential of the industrial enterprise is } \\
\text { accompanied by high incomes of the employees, } \\
\text { resources of the enterprise for carrying out the } \\
\text { socio-economic policy, which inhibit the decline } \\
\text { of consumer demand and amortize the decline of } \\
\text { output. } \\
\text { The greater the diversification, the greater the } \\
\text { number of products involved in the production } \\
\text { and trade turnover of enterprises, the shock at an } \\
\text { individual enterprise compensated by the } \\
\text { development of another segment of the value } \\
\text { chain, and the flexible redistribution of resources. } \\
\text { A diversified value chain is characterized by } \\
\text { mobility, but where mono-specialization makes } \\
\text { rapid adaptation difficult or impossible. }\end{array}$ \\
\hline 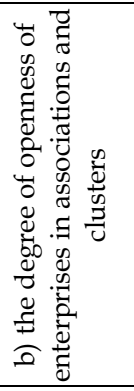 & $\begin{array}{l}\text { Coefficient of initial specialization, } \mathrm{K}_{\mathrm{B.спец,}} \% \\
\mathrm{~K}_{\text {в.спец }}=\frac{Q_{\mathrm{B}}}{\sum Q} \cdot 100 \%, \\
\text { where } Q_{\mathrm{B}} \text { - Output of resources, products, thousands } \\
\text { Ratio of resource or product outflows and receipts } \mathrm{K}_{\mathrm{B} / \mathrm{H}}= \\
\frac{Q_{\mathrm{B}}}{Q_{\mathrm{H}}} \\
Q_{\mathrm{H}} \text { - receipt of resources, products, thousand UAH }\end{array}$ & $\begin{array}{l}\text { The response to the shock is determined by the } \\
\text { degree of involvement and openness in the value } \\
\text { chain from one enterprise to another in the chain } \\
\text { and the share of revenues in domestic } \\
\text { consumption. } \\
\text { A high level of involvement in production and } \\
\text { trade influences the enterprise, to a greater extent, } \\
\text { if the orientation of economic development and } \\
\text { the direction of the shock (from the point of exit / } \\
\text { entry) coincide will not affect the chain of } \\
\text { production or trade. }\end{array}$ \\
\hline \multicolumn{3}{|c|}{ Investment communication channel } \\
\hline 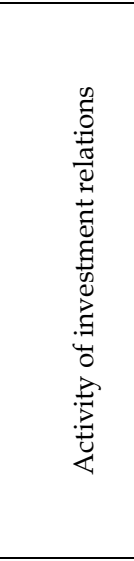 & $\begin{array}{l}\text { Amount of investment (capital) of the enterprise in the total } \\
\text { amount of consolidated capital, } \% \\
d=\frac{i_{\text {під }}}{\sum \mathrm{i}_{\text {chain }}} \cdot 100 \% \text {, where } i_{\text {під- investments of the }} \\
\text { enterprise, thousand UAH } \\
\sum \mathrm{i}_{\text {chain }} \text { - value chain investments, UAH thousand } \\
\text { Investment growth rate, } \mathrm{T}_{\Pi p . \mathrm{i}}, \% \\
\mathrm{~T}_{\Pi \text { п.i }}=\frac{i_{n}}{i_{n-1}} \cdot 100 \% \text {, where } i_{n-1} \text { - investments of the } \\
\text { i-th period, thousand UAH } \\
\text { Investment potential and investment risk } \\
R_{i} \text { ноp }=\frac{R_{i}}{R_{i_{\text {median }}}} \text {, where } R_{i_{\text {median }}} \text { the average chain } \\
\text { value of investment risk for the period. }\end{array}$ & $\begin{array}{l}\text { The strength of the localized investments of each } \\
\text { participating enterprise, the high investment } \\
\text { potential of the value chain and the low risk are } \\
\text { positive factors in sustaining development. } \\
\text { If the external shock is related to the investment } \\
\text { component, it immediately affects the economic } \\
\text { capacity of the enterprise, the investment } \\
\text { demand, the depth of the impact depends on the } \\
\text { scale of the investment and the localization of } \\
\text { enterprises (priority, dominant or other economic } \\
\text { activities). }\end{array}$ \\
\hline
\end{tabular}

*Made by author.

These indicators show the different economic conditions in which shocks or impulses are transmitted and make it possible to identify specific characteristics of enterprises in clusters, clusters or value chains. At the same time, the analysis of changes in the indicators over time allows to expand the 
understanding of the influence of external institutional shock, a certain reaction of a group of enterprises, the processes of «restructuring» and the transformations of internal parameters as a result of the shock.

So, given the diversity of scientific and methodological approaches to assessing integration risks, financial security and the impact of shocks on the parameters of clusters, clusters or value chains, their main limitation is a low level of adaptation to the trend, established during the development of unification, which reduces the reliability of economic and mathematical models and strategizing processes. Taking into account this limitation, the proposed approach makes it possible to determine the changes in the parameters of the «capacity» of the circuits and the investment channels of the shock pulse propagation on the economic potential and strategic elasticity of the structure of the associations, clusters or value chains of enterprises.

\section{CONCLUSIONS}

Thus, the modeling of integration risks by value chains in economic emergence is aimed at identifying hazards that arise at different stages of the integration process, and at the second stage is oriented towards the performance of the system as a result of the integration. The features of the simulation are to account for the influence of unpredictable integration factors at the bifurcation point when positive and negative emergent properties occur. The formation of the model should lay down the vectors of the integration process, depending on the adaptive capacity of the new structural units (institutions). Examining the integration of industrial enterprises in the context of value chain formation, the focus remains on value added and efficiency of integration, which comes after the creation of new structures and institutions, influences the achievement of strategic elasticity of the integrated structure of enterprises and organizations.

\section{REFERENCES}

1. Hryhoruk P. M., Khrushch N. A. Intehralne otsiniuvannia rivnia ta dynamiky innovatsiinoho potentsialu rehionu. Marketynh i menedzhment innovatsii. 2016. № 3. S. 109-129. URL: http://nbuv.gov.ua/UJRN/Mimi_2016_3_11

2. Hryhoruk P. M., Khrushch N. A. Metodolohichni zasady modeliuvannia systemy zabezpechennia finansovoekonomichnoi bezpeky v umovakh nevyznachenosti i bahatomirnosti rynkovoho seredovyshcha. Naukovyi visnyk Mukachivskoho derzhavnoho universytetu. Ser. : Ekonomika. 2017. V.1. S. 198-204. URL: http://nbuv.gov.ua/UJRN/nvmdue_2017_1_35

3. Hurochkina V. V. Mekhanizmy rozvytku promyslovykh pidpryiemstv v emerdzhentnii ekonomitsi : monohrafiia / V. V. Hurochkina. Khmelnytskyi : KhNU, 2020. 336 s.

4. Hurochkina V. V., Menchynska O. M. Osoblyvosti formuvannia ta funktsionuvannia intehrovanykh struktur v hlobalnykh lantsiuhakh stvorennia vartosti. Visnyk Khmelnytskoho natsionalnoho universytetu. Ekonomichni nauky. 2020. № 3. S. 248-257 DOI: 10.31891/2307-5740-2020-282-3-43 URL: http://ir.nusta.edu.ua/jspui/bitstream/123456789/6096/1/6288_IR.pdf

5. Hurochkina V.V. Finansovi ta intehratsiini mekhanizmy rozvytku promyslovykh pidpryiemstv v emerdzhemntnii ekonomitsi : dys. ... d-ra эkon. nauk : 08.00 .04 / V.V. Hurochkina. - Khmelnytskyi., 2020. - 570 s.

6. Pidpryiemnytstvo v epokhu hlobalnykh transformatsii: vyklyky ta perspektyvy rozvytku : monohrafiia / [P. V. Pashko, L. L. Lazebnyk, Yu. V. Kindzerskyi ta in.] ; za red. P. V. Pashka ta L. L. Lazebnyk ; Universytet derzhavnoi fiskalnoi sluzhby Ukrainy. Irpin : vyd.-polihraf. tsentr Universytetu DFS Ukrainy, 2019. 476 s. (Seriia «Podatkova ta mytna sprava v Ukraini», t. 133).

7. Hryhoruk P. M., Khrushch N. A., Grygoruk S. S. An approach to construct fuzzy preference relationships for managerial decision making. Scientific bulletin of Polissya. 2017. Vol. 4 (12), no. 2. Pp. 92-99. Doi: 10.25140/2410-9576-2017-2-4(12)92-99

8. Voynarenko M, Dzhedzhula V., Yepifanova I. Modeling of the process of personnel motivation for innovation activity WSEAS Transactions on Business and Economics, 17, 2020, rr. 467-477

9. Voynarenko M., Lazebnyk L., Hurochkina V., Kovalenko O. and Menchynska O., Modeling Emergence Properties of Economic System. 2020 10th International Conference on Advanced Computer Information Technologies (ACIT), Deggendorf, Germany, 2020, pp. 607-612, DOI: 10.1109/ACIT49673.2020.9208954. https://www.scopus.com/authid/detail.uri?authorId=57219594843

10. Voynarenko M., Dzhedzhula V., Yepifanova, I. Modelling the process of making decisions on sources of financing of innovation activity. Economic Annals-XXI, 160(7-8), 2016, rr. 126-129.

11. Gonchar O. I. Anagement potential of the company with regard flock business life. Naukovyi visnyk Polissia. 2016. №3 (7). C. 190-196

12. Hryhoruk P. M. Khrushch N. A. Metodolohichni zasady modeliuvannia systemy zabezpechennia finansovoekonomichnoi bezpeky v umovakh nevyznachenosti i bahatomirnosti rynkovoho seredovyshcha. Naukovyi visnyk Mukachivskoho derzhavnoho universytetu. Seriia: Ekonomika : zb. nauk. pr. Mukachevo, 2017. Vyp. 1. S. 198-204.

13. Hryhoruk P., Khrushch N., Grygoruk S. Assessment model of regions economy in the context of their sustainable development. E3S Web of Conferences. 2020. No 166. paper number 13023.: URL https://cutt.ly/Igs9Ii1. doi: https://doi.org/10.1051/e3sconf/202016613023

14. Hryhoruk P. Khrushch N. Simulation of financial decision-making process in system of insuring sustainable development. Sustainable Development: Social and Economic Changes : Monograph / Ed. by dr Wojciech Duczmal, dr Tadeusz Pokusa, dr Larysa Stepanenko; The Academy of Management and Administration in Opole. Opole : Publishing House WSZiA, 2016. P. 231-236. 


\section{МЕТОДОЛОГІЧНІ ЗАСАДИ МОДЕЛЮВАННЯ ІНТЕГРАЦЙНИХ РИЗИКІВ СИСТЕМИ В ЕМЕРДЖЕНТНІЙ ЕКОНОМІЦ}

\section{ВІКТОРІЯ ГУРОЧКІНА}

Університет державної фіскальної служби України

У статті розглянуто методологічні засади моделювання інтеграційних ризиків соціально-економічної системи, а саме об'єднання підприємств та організацій у ланиюги створення доданої вартості в умовах емерджентної економіки. Представлено теоретичну базу та визначено практичні аспекти щуодо ризикологї інтеграційних процесів, виявлено особливості інтеграцї та методи моделювання ризиків у ланиюгах створення доданої вартості $b$ соиіально-економічних системах. Систематизовано таксономічний огляд емерджентного стану соціально-економічної системи. Представлено складові механізму інтеграції підприємств в контексті формування ланцюгів створення доданої вартості та визначено найбільш дієві методи моделювання у нестабільному середовищі. Наведено методологічні засади моделювання показників за умов впливу інвестиційних ризиків на основі нечіткої логіки за критерієм безпеки системи, засади порівняльного оцінювання при моделюванні інтеграційних ризиків у ланцюгах доданої вартості та засади моделювання інтеграційних ризиків економічного потенціалу та стратегічної пружності соціально-економічної системи.

Ключові слова: система, моделювання, емерджентність, емерджентні властивості, таксономія, інтеграційні ризики. 